\title{
Bibliography of secondary sources
}

Abu-Lughod, Janet L., Before European Hegemony: The World System A.D. 12501350 (Oxford: Oxford University Press, 1989)

Adhikari, Mohamed, The Anatomy of a South African Genocide: The Extermination of the Cape San Peoples (Athens: Ohio University Press, 2011)

Agathocleous, Tanya, 'Imperial, Anglophone, Geopolitical, Worldly: Evaluating The "Global" in Victorian Studies', Victorian Literature and Culture, 43 (2015), 651-8

- and Jason R. Rudy, 'Victorian Cosmopolitanisms', Victorian Literature and Culture, 38 (2010), 389-97

Albuquerque, Sara, 'Glimpses of British Guiana at the Colonial and Indian Exhibition, 1886', Culture and History Digital Journal, 5.1 (2016), n.p., http://cultureandhistory.revistas.csic.es/index.php/cultureandhistory/article/view/97/333 (accessed 1 February 2020)

ALICE, http://alice.ces.uc.pt/en/ (accessed 26 June 2019)

Allam, Lorena, and Carly Earl, 'For Centuries the Rivers Sustained Aboriginal Culture. Now They Are Dry, Elders Despair' (21 January 2019), n.p., www.theguardian. com/australia-news/2019/jan/22/murray-darling-river-aboriginal-culture-dryelders-despair-walgett (accessed 10 November 2019)

Allan, Michael, 'Reading with One Eye, Speaking with One Tongue: On the Problem of Address in World Literature', Comparative Literature, 44.1-2 (2007), 1-19

Allen, Chadwick, Blood Narrative: Indigenous Identity in American Indian and Maori Literary and Activist Texts (Durham and London: Duke University Press, 2002)

- 'Decolonizing Comparison: Toward a Literary Studies', in The Oxford Handbook of Indigenous American Literature, ed. by James H. Cox and Daniel Heath Justice (Oxford: Oxford University Press, 2014), 377-94

- Trans-Indigenous: Methodologies for Global Native Literary Studies (Minneapolis: University of Minnesota Press, 2012)

- 'A Transnational Native American Studies?', n.p., https://escholarship.org/uc/ item/82m5j3f5 (accessed 26 June 2019)

Anderson, Benedict, Imagined Communities: Reflections on the Origin and Spread of Nationalism (London: Verso, 1983)

- The Spectre of Comparisons: Nationalism, Southeast Asia and the World (London: Verso, 1998)

Anderson, Margaret, 'Mrs. Charles Clacy, Lola Montez, and Poll the Grogseller: Glimpses of Women on the Early Victorian Goldfields', in Gold: Forgotten Histories and Lost Objects of Australia, ed. by Iain McCalman, Alexander Cook, and Andrew Reeves (Cambridge and New York: Cambridge University Press, 2001), pp. 225-49 
Anderson, Warwick, 'Racial Conceptions in the Global South', ISIS, 15.4 (2014), 782-92 Appadurai, Arjun, 'Disjuncture and Difference in the Global Cultural Economy', in The Phantom Public Sphere, ed. by Bruce Robbins (Minneapolis: University of Minnesota Press, 1993), pp. 269-96

Araluen, Evelyn, 'Resisting the Institution', Overland, 227 (2017), n.p., https://overland. org.au/previous-issues/issue-227/feature-evelyn-araluen/ (accessed 26 June 2019)

Archibald, Jo-Ann, Jenny Lee-Morgan, and Jason De Santolo, eds, Decolonizing Research: Indigenous Storywork as Methodology (London: Zed, 2019)

Armitage, David, Alison Bashford, and Sujit Sivasundaram, 'Introduction: Writing World Oceanic Histories', in Oceanic Histories, ed. by David Armitage, Alison Bashford, and Sujit Sivasundaram (Cambridge: Cambridge University Press, 2018), pp. 1-28

Atkin, Lara, "The South African "Children of the Mist": The Bushman, the Highlander and the Making of Colonial Identities in Thomas Pringle's South African Poetry (1825-1834)', The Yearbook of English Studies, 48 (2018), 199-215

- Sarah Comyn, Porscha Fermanis, and Nathan Garvey, Early Public Libraries and Colonial Citizenship in the British Southern Hemisphere (Cham: Springer International Publishing, 2019)

Atkinson, Alan, The Europeans in Australia: A History, Vol. 1, The Beginning (Oxford: Oxford University Press, 1997)

Attwell, David, 'Reprisals of Modernity in Black South African "Mission” Writing', Journal of Southern African Studies, 25.2 (1999), 267-85

- and Derek Attridge, eds, The Cambridge History of South African Literature (Cambridge: Cambridge University Press, 2012)

Atwood, Bain, Possession: Batman's Treaty and the Matter of History (Melbourne: Melbourne University Press, 2009)

Auerbach, Jeffrey, Imperial Boredom: Monotony and the British Empire (Oxford: Oxford University Press, 2018)

Ballantyne, Tony, 'Christianity, Commerce, and the Remaking of the Māori World', in Facing Empire: Indigenous Experience in a Revolutionary Age, ed. by Kate Fullagar and Michael McDonnell (Baltimore: Johns Hopkins Press, 2018), pp. 192-213

— 'Mobility, Empire, Colonisation', History Australia, 11.2 (2014), 7-37

- 'Putting the Nation in its Place? World History and C. A. Bayly's The Birth of the Modern World', in Connected Worlds: History in Transnational Perspective, ed. by Anne Curthoys and Marilyn Lake (Canberra: ANU Press, 2005), pp. 23-44

- 'Strategic Intimacies: Knowledge and Colonization in Southern New Zealand', Journal of New Zealand Studies, 14 (2013), 4-18

Ballard, Charles, John Dunn: The White Chief of Zululand (Johannesburg: Ad Donker, 1985)

Banivanua Mar, Tracey, Decolonisation and the Pacific: Indigenous Globalisation and the Ends of Empire (New York: Cambridge University Press, 2016)

- 'Imperial Literacy and Indigenous Rights: Tracing Transoceanic Circuits of a Modern Discourse', Aboriginal History, 37 (2013), 1-28

- 'Shadowing Imperial Networks: Indigenous Mobility and Australia's Pacific Past', Australian Historical Studies, 46.3 (2015), 340-55

- Violence and Colonial Dialogue: The Australian-Pacific Indentured Labor Trade (Honolulu: University of Hawai'i Press, 2007)

— and Nadia Rhook, 'Counter Networks of Empires: Reading Unexpected People in Unexpected Places', Journal of Colonialism and Colonial History, 19.2 (Summer 2018), n.p., https://muse.jhu.edu/article/700162 (accessed 26 June 2019) 
Bank, Andrew, 'The Great Debate and the Origins of South African Historiography', The Journal of African History, 38.2 (1997), 261-81

Barrell, John, English Literature in History, 1730-80: An Equal, Wide Survey (London: Hutchinson, 1983)

Bauer, Ralph, 'Hemispheric Studies', PMLA, 124.1 (2009), 234-50

Bayly, C. A., Sven Beckert, Matthew Connelly, Isabel Hofmeyr, Wendy Kozol, Patricia Seed, 'AHR Conversation: On Transnational History', The American Historical Review, 111.5 (2006), 1441-64

Beckett, Gorden, The Colonial Economy of NSW: A Retrospective between 1788 and 1835 (Singapore: Trafford, 2012)

Belgrave, Michael, Historical Frictions: Maori Claims \& Reinvented Histories (Auckland: Auckland University Press, 2005)

Belich, James, Replenishing the Earth: The Settler Revolution and the Rise of the Anglo-World, 1783-1939 (New York and Oxford: Oxford University Press, 2009)

Bell, Bill, 'Bound for Australia: Shipboard Reading in the Nineteenth Century', Journal of Australian Studies, 25 (2001), 5-18

-- 'Crusoe's Books: The Scottish Emigrant Reader in the Nineteenth Century', in Across Boundaries: The Book in Culture and Commerce, ed. by Bill Bell, Philip Bennett, and Jonquil Bevan (Winchester: Oak Knoll Press, 2000), pp. 116-29

Bell, Leonard, 'Augustus Earle's The Meeting of the Artist and the Wounded Chief Hongi, Bay of Islands, New Zealand, 1827, and His Depictions of Other New Zealand Encounters', in Voyages and Beaches: Pacific Encounters, 1769-1840, ed. by Alex Calder, Jonathan Lamb, and Bridget Orr (Honolulu: University of Hawai'i Press, 1999), pp. 241-63

- 'Not Quite Darwin's Artist: The Travel Art of Augustus Earle', Journal of Historical Geography, 43 (2014), 60-70

- 'To See or Not to See: Conflicting Eyes in the Travel Art of Augustus Earle', in Orientalism Transposed; the Impacts of the Colonies on British Culture, ed. by Julie F. Codell and Dianne Sachko Macleod (Aldershot and Brookfield: Ashgate, 1998), pp. 117-39

Benjamin, Walter, Illuminations, trans. by Harry Zorn, ed. by Hannah Arendt (London: Pimlico, 1999)

Bennett, Bruce, 'The Trader's Eye: Louis Becke’s Oceania', SPAN, 48-9 (1999), 150-8

Bennett, Melissa, and Kristy Warren, 'Looking Back and Facing Forwards: Ten Years of the London, Sugar \& Slavery Gallery', Journal of Historical Geography, 63 (2019), 94-9

Bentley, Trevor, Pakeha Maori: The Extraordinary Story of the Europeans who Lived as Maori in Early New Zealand (Auckland: Penguin, 1999)

Bernasconi, Robert, 'The Paradox of Liberal Politics in the South African Context: Alfred Hoernlé's Critique of Liberalism's Pact with White Domination', Critical Philosophy of Race, 4.2 (2016), 163-81

Bewell, Alan, Natures in Translation: Romanticism and Colonial Natural History (Baltimore and London: Johns Hopkins University Press, 2017)

- Romanticism and Colonial Disease (Baltimore and London: Johns Hopkins University Press, 2003)

Bhabha, Homi K., 'Introduction', in Nation and Narration, ed. by Homi K. Bhabha (London and New York: Routledge 1990), pp. 1-7 
Bhattacharya, Sumangala, “"The White Lady and the Brown Woman”: Colonial Masculinity and Domesticity in Louis Becke's By Reef and Palm (1894)', in Oceania and the Victorian Imagination: Where All Things Are Possible, ed. by Richard D. Fulton and Peter H. Hoffenberg (Farnham: Ashgate, 2013), pp. 79-92

Binney, Judith, 'Tuki's Universe', New Zealand Journal of History, 38.2 (2004), 215-32

— with Vincent O'Malley and Alan Ward, Te Ao Hou: The New World, 1820-1920 (Wellington: Bridget Williams Books, 2018)

Blaser, Mario, 'Ontology and Indigeneity: On the Political Ontology of Heterogeneous Assemblages', Cultural Geographies, 2.1 (2014), 49-58

Bode, Katherine, 'Fictional Systems: Mass-Digitization, Network Analysis, and Nineteenth-Century Australian Newspapers', Victorian Periodicals Review, 50.1 (2017), 100-38

- Reading by Numbers: Recalibrating the Literary Field (London: Anthem Press, 2012)

— “'Sidelines” and Trade Lines: Publishing the Australian Novel, 1860-1899', Book History, 15 (2012), 93-122

— 'Thousands of Titles Without Authors: Digitized Newspapers, Serial Fiction, and the Challenges of Anonymity', Book History, 19 (2016), 284-316

Boehmer, Elleke, Colonial and Postcolonial Literature: Migrant Metaphors (Oxford: Oxford University Press 1995)

- Empire, the National and the Postcolonial: Resistance in Interaction (Oxford: Oxford University Press, 2002)

- Postcolonial Poetics: 21st-Century Critical Readings (Basingstoke: Palgrave Macmillan, 2018)

Bonyhady, Tim, Images in Opposition: Australian Landscape Painting, 1801-1890 (Oxford: Oxford University Press, 1984)

Bose, Sugata, A Hundred Horizons: The Indian Ocean in the Age of Global Empire (Cambridge, MA: Harvard University Press, 2006)

Boult, Trevor, St Helena: A Maritime History (Stroud: Amberley, 2016)

Bradshaw, Ann Lane, 'Joseph Conrad and Louis Becke', English Studies, 86.3 (2005), 206-25

Brantlinger, Patrick, Dark Vanishings: Discourse on the Extinction of Primitive Races, 1800-1930 (Ithaca: Cornell University Press, 2003)

- Taming Cannibals: Victorians and Race (Cornell: Cornell University Press, 2011)

Brett, André, 'Colonial and Provincial Separation Movements in Australia and New Zealand, 1856-1865', The Journal of Imperial and Commonwealth History, 47.1 (2019), 51-75

Breward, Christopher, Fashioning London: Clothing and the Modern Metropolis (Oxford: Berg, 2004)

Buchanan, Susan Locher, Burchell's Travels: The Life, Art and Journeys of William John Burchell (Cape Town: Penguin Books, 2015)

Burton, Antoinette, and Isabel Hofmeyr, 'Introduction', in Ten Books That Shaped the British Empire: Creating an Imperial Commons, ed. by Antoinette Burton and Isabel Hofmeyr (Durham: Duke University Press, 2014), pp. 1-28

Buse, Jasper, and Raututi Taringa, Cook Islands Maori Dictionary, ed. by Bruce Biggs and Rangi Moeka'a (Rarotonga: The Ministry of Education, Government of the Cook Islands / London: School of Oriental and African Studies, University of London / Suva: Institute of Pacific Studies, University of the South Pacific / 
Auckland: Centre for Pacific Studies, University of Auckland / Canberra: Pacific Linguistics, Research School of Pacific and Asian Studies, Australian National University, 1995)

Butler, Marilyn, Mapping Mythologies: Counter-Currents in Eighteenth-Century British Poetry and Cultural History (Cambridge: Cambridge University Press, 2015)

Calder, Alex, The Settler's Plot: How Stories Take Place in New Zealand (Auckland: Auckland University Press, 2011)

Carey, Hilary M., 'Lancelot Threlkeld and Missionary Linguistics in Australia to 1850', in Missionary Linguistics / Lingüistica Misionera: Selected Papers from the First International Conference on Missionary Linguistics, Oslo, March 13th-16th, 2003, ed. by Otto Zwartjes and Even Hovdhaugen (Amsterdam: John Benjamins, 2004), pp. 253-75

- 'Lancelot Threlkeld, Biraban, and the Colonial Bible in Australia', Comparative Studies in Society and History, 52.2 (2010), 447-78

Carruthers, Jane, and Marion Arnold, The Life and Work of Thomas Baines (Cape Town: Fernwood Press, 1995)

Carter, David, 'After Postcolonialism', Meanjin, 66.2 (2007), 114-9

Carter, Paul, 'Australindia: The Geography of Imperial Desire', Postcolonial Studies, 18 (2015), 222-33.

- The Road to Botany Bay (London: Faber, 1987)

Cassano, Franco, Southern Thought and other Essays on the Mediterranean, trans. and ed. by Norma Bouchard and Valerio Ferme (New York: Fordham University Press, 2012)

Castellanos, Bianet, Lourdes Gutiérrez Nájera, and Arturo Aldama, eds, Comparative Indigeneities of the Américas: Toward a Hemispheric Approach (Tucson: University of Arizona Press, 2012)

Chakrabarty, Dipesh, Provincializing Europe: Postcolonial Thought and Historical Difference (Princeton: Princeton University Press, 2000)

Chander, Manu Samriti, Brown Romantics: Poetry and Nationalism in the Global Nineteenth Century (Lewisburg: Bucknell University Press, 2017)

Chandler, David, and Julian Reid, “Being in Being”: Contesting the Ontopolitics of Indigeneity', The European Legacy, 23.3 (2018), 251-68

Chang, David A., 'The Good Written Word of Life: Native Hawaiian Appropriation of Textuality', William and Mary Quarterly, 75.2 (2018), n.p.

Clarke, Patricia, Pioneer Writer: The Life of Louisa Atkinson: Novelist, Journalist, Naturalist (Sydney: Allen \& Unwin, 1990)

Clifford, James, 'Indigenous Articulations', in The Worlding Project: Doing Cultural Studies in the Era of Globalization, ed. by Rob Wilson and Christopher Leigh Connery (Berkeley: New Pacific Press, 2007), pp. 13-39

- 'Notes on Travel and Theory', Centre for Cultural Studies Inscriptions, 5 (1989), n.p., https://culturalstudies.ucsc.edu/inscriptions/volume-5/james-clifford/ (accessed 5 July 2019)

— 'The Others: Beyond the "Salvage" Paradigm', Third Text, 3.6 (1989), 73-8

- Returns: Becoming Indigenous in the Twenty-First Century (Cambridge, MA: Harvard University Press, 2013)

Codell, Julie F., 'Introduction: Imperial Co-histories and the British and Colonial Press', in Imperial Co-histories: National Identities and the British and Colonial Press, ed. by Julie F. Codell (Danvers: Rosemount, 2003), pp. 15-28

Coetzee, J. M., 'Farm Novel and "Plaasroman" in South Africa', English in Africa, 13.2 (1986), 1-19. 
- White Writing: On the Culture of Letters in South Africa (Sandton: Radix, 1988)

Coetzee, P. H., and A. P. J. Roux, The African Philosophy Reader (London and New York: Taylor \& Francis, 2004)

Coleman, Deirdre, Romantic Colonization and British Anti-Slavery (Cambridge: Cambridge University Press, 2005)

Coleman, Julie, A History of Cant and Slang Dictionaries: Volume 2: 1785-1858 (Oxford: Oxford University Press, 2004)

Colley, Linda, Britons: Forging the Nation 1707-1837 (New Haven: Yale University Press, 1992)

Collins, Patrick, Goodbye Bussamarai: The Mandandanji Land War, Southern Queensland, 1842-1852 (St. Lucia: University of Queensland Press, 2002)

Collis-Buthelezi, Victoria, 'Caribbean Regionalism, South Africa, and Mapping New World Studies', Small Axe, 19.1 (2015), 37-54

- 'Under the Aegis of Empire: Cape Town, Victorianism, and Early-Twentieth-Century Black Thought', Callaloo, 39.1 (2016), 115-32

Comaroff, Jean, and John Comaroff, 'Theory from the South: A Rejoinder', Cultural Anthropology Online, 25 February 2012, n.p., https://culanth.org/fieldsights/theoryfrom-the-south-a-rejoinder (accessed 24 June 2019)

- Theory from the South: Or, How Euro-America Is Evolving Toward Africa (Boulder: Paradigm Publishers, 2011)

Comment, Bernard, The Panorama (London: Reaktion Books, 1999)

Comyn, Sarah, and Porscha Fermanis, 'Rethinking Nineteenth-Century Literary Culture: British Worlds, Southern Latitudes and Hemispheric Methods', Journal of Commonwealth Literature (2021), n.p., https://doi.org/10.1177/0021989420982013 (accessed 1 February 2021)

Connell, Raewyn, Southern Theory: The Global Dynamics of Knowledge in Social Science (Sydney: Allen \& Unwin, 2007)

Cooppan, Vilashini, 'The Corpus of a Continent: Embodiments of Australia in World Literature', JASAL: Journal of the Association for the Study of Australian Literature, 15.3 (2015), 1-19

Coulthard, Glen, Red Skin, White Masks: Rejecting the Colonial Politics of Recognition (Minneapolis: University of Minnesota Press, 2014)

Cranston, C. A., and Charles Dawson, 'Climate and Culture in Australia and New Zealand', in A Global History of Literature and the Environment, ed. by John Parham and Louise Westling (Cambridge: Cambridge University Press, 2016), pp. 239-53

Critchett, Jan, 'A Distant Field of Murder': Western Districts Frontiers, 1834-1848 (Melbourne: Melbourne University Press, 1990)

Crocombe, Marjorie Tua'inekore, 'Tata: Expression Through the Written Word', in Akono'anga Maori: Cook Islands Culture, ed. by Ron Crocombe and Marjorie Tua'inekore Crocombe (Suva: Institute of Pacific Studies, in association with the Cook Islands Extension Centre, University of the South Pacific / Rarotonga: Cook Islands Cultural and Historic Places Trust, and the Ministry of Cultural Development, 2003), pp. 81-91

Crocombe, Ron G., 'Land Tenure in the Cook Islands' (unpublished doctoral thesis, Australian National University, 1961), New Zealand Electronic Text Collection: Te Pühikotuhi o Aotearoa (Victorian University of Wellington, 2016), n.p., nzetc. victoria.ac.nz/tm/scholarly/tei-CroLan.html (accessed 31 January 2020)

Crosby, Alfred, Ecological Imperialism: The Biological Expansion of Europe, 9001900 (Cambridge: Cambridge University Press, 1986) 
Crouch, David, Colonial Psychosocial: Reading William Lane (Newcastle upon Tyne: Cambridge Scholars Publishing, 2015)

Curless, Gareth, Stacey Hynd, Temilola Alanamu, and Katherine Roscoe, 'Editor's Introduction: Networks in Imperial History', Journal of World History, 26.4 (2016), 705-32

Curling, Jonathan, Janus Weathercock: The Life of Thomas Griffiths Wainewright (London: Nelson, 1938)

Currey, C. H., 'Field, Barron (1786-1846)', Australian Dictionary of National Biography, n.p., https://adb.anu.edu.au/biography/field-barron-2041/text2523 (accessed 12 February 2020)

Dainotto, Roberto M., Europe (In Theory) (Durham: Duke University Press, 2007)

Daniels, Kay, 'Feminism and Social History', Australian Feminist Studies, 1 (1985), 27-40

Dart, Gregory, 'Flash Style: Pierce Egan and the Literary Culture of the 1820s', History Workshop Journal, 51 (2001), 181-205

Dassow Walls, Laura, The Passage to Cosmos: Alexander Humboldt and the Shaping of America (Chicago: Chicago University Press, 2009)

Davidson, Graeme, City Dreamers: The Urban Imagination in Australia (Sydney: NewSouth Publishing, 2016)

Davies, Dominic, Imperial Infrastructure and Spatial Resistance in Colonial Literature, 1880-1930 (Oxford: Peter Lang, 2017)

Day, A. Grove, 'By Reef and Tide: Louis Becke's Literary Reputation', Australian Letters, 6.1 (1963), 17-26

Day, Iyko, 'Being or Nothingness: Indigeneity, Antiblackness, and Settler Colonial Critique', Critical Ethnic Studies, 1.2 (2015), 102-21

Deb, Nilanjana, '(Re)moving Bodies: People, Ships and Other Commodities in the Coolie Trade from Calcutta', in Commodities and Culture in the Colonial World, ed. by Supriya Chaudhuri, Josephine McDonagh, Bryan Murray, and Rajeswari Rajan (London: Routledge, 2018), pp. 115-28

Delmas, Adrien, 'Introduction: The Written Word and the World', in Written Culture in a Colonial Context: Africa and the Americas 1500-1900, ed. by Adrien Delmas and Nigel Penn (Leiden: Brill, 2012), pp. 95-122

Deloria, Philip, Indians in Unexpected Places (Lawrence: University Press of Kansas, 2004)

DeLoughrey, Elizabeth, Routes and Roots: Navigating Caribbean and Pacific Island Literatures (Honolulu: University of Hawai'i i Press, 2010)

- Jill Didur, and Anthony Carrigan, 'Introduction: A Postcolonial Environmental Humanities', in Global Ecologies and the Environmental Humanities, ed. by Elizabeth DeLoughrey, Jill Didur, and Anthony Carrigan (London and New York: Routledge, 2015), pp. 1-32

Dening, Greg, Mr Bligh's Bad Language: Passion, Power, and Theatre on the Bounty (Cambridge: Cambridge University Press, 1992)

De Schmidt, Johanna, “"This Strange Little Floating World of Ours”: Shipboard Periodicals and Community-Building in the "Global" Nineteenth Century", Journal of Global History, 11 (2016), 229-50

Diagne, Souleymane Bachir, 'Individual, Community, and Human Rights', Transition, 101 (2009), 8-15

Dias, Vicente M., and J. Kehaulani Kauanui, 'Native Pacific Cultural Studies on the Edge', The Contemporary Pacific, 13.2 (2001), 315-42

Dick, Archie L., The Hidden History of South Africa's Book and Reading Cultures (Toronto and London: University of Toronto Press, 2012) 
Dine, Philip, 'Horse Racing in Early Colonial Algeria: From Anglophilia to Arabomania', in Sporting Cultures, 1650-1850, ed. by Daniel O'Quinn and Alexis Tadié (Toronto: University of Toronto Press, 2018), pp. 136-60

Dingley, Robert, 'The Ruins of the Future: Macaulay's New Zealander and the Spirit of the Age', in Histories of the Future: Studies in Fact, Fantasy and Science Fiction, ed. by A. Sandison and R. Dingley (Basingstoke: Palgrave, 2000), pp. 15-33

Dixon, Robert, 'Australian Literature-International Contexts', Southerly, 67.1/2 (2007), 15-27

Dominy, Graham, 'Thomas Baines and the Langalibalele Rebellion: A Critique of an Unrecorded Sketch of the Action at "Bushman's Pass", 1873', Natal Museum Journal of Humanities, 3 (1991), 41-55

— 'Thomas Baines: The McGonagall of Shepstone's 1873 Zululand Expedition?', Natalia, 21 (1991), 75-9

Donaldson, Mike, 'The End of Time? Aboriginal Temporality and the British Invasion of Australia', Time and Society, 5.2 (1996), 187-207

Dooling, Wayne, 'The Origins and Aftermath of the Cape Colony's "Hottentot Code" of 1809', Kronos, 31 (2005), 50-61

Doran, Christine, 'Singapore', in The Edinburgh Companion to the History of Democracy, ed. by Benjamin Isakhan and Stephen Stockwell (Edinburgh: Edinburgh University Press, 2012) pp. 257-70

Douglas, Bronwen, 'Foreign Bodies in Oceania', in Foreign Bodies: Oceania and the Science of Race, 1750-1940, ed. by Bronwen Douglas and Chris Ballard (Canberra: Australian National University Press, 2008), pp. 3-32

Driver, Felix, and Lowri Jones, Hidden Histories of Exploration: Researching the RGS-IBG Collections (London: Royal Holloway, University of London, with the Royal Geographical Society, 2009)

Driver-Burgess, Frith, 'Korero Pukapuka, Talking Books: Reading in Reo Māori in the Long Nineteenth Century' (unpublished master's thesis, Victoria University of Wellington, 2015)

Dubow, Saul, 'How British was the British World? The Case of South Africa', The Journal of Imperial and Commonwealth History, 37.1 (2009), 1-27

- Scientific Racism in Modern South Africa (Cambridge: Cambridge University Press, 1995)

Dunk, Jonathan, 'Reading the Tracker: The Antimonies of Aboriginal Ventriloquism', JASAL: Journal of the Association for the Study of Australian Literature, 17.1 (2017), 1-12

Durie, Mason, Te Mana, Te Kāwanatanga: The Politics of Māori Self-Determination (Auckland: Oxford University Press, 1998)

Dusinberre, Martin, and Roland Wenzlhuemer, 'Editorial - Being in Transit: Ships and Global Incompatibilities', Journal of Global History, 11.2 (2016), 155-62

Du Toit, André, 'Critic and Citizen: The Intellectual, Transformation and Academic Freedom', Pretexts: Literary and Cultural Studies, 9.1 (2000), 91-104

— 'The Legacy of Daantjie Oosthuizen: Revisiting the Liberal Defence of Academic Freedom', African Sociological Review / Revue Africaine de Sociologie, 9.1 (2005), 40-61

— and Hermann Buhr Giliomee, Afrikaner Political Thought: Volume One: 1780-1850 (Claremont: David Philip, 1983)

Dwyer, Philip G, and Lyndall Ryan, 'Massacre in the Old and New Worlds, c.17801820', Journal of Genocide Research, 15.2 (2013), 111-15 
Eagleton, Terry, Literary Theory: An Introduction (Oxford: Blackwell, 1983)

Edmonds, Penelope, "I followed England round the world”: The Rise of Trans-Imperial Anglo-Saxon Exceptionalism and the Spatial Narratives of Nineteenth-Century British Settler Colonies of the Pacific Rim', in Reorienting Whiteness, ed. by Leigh Boucher, Jane Carey, and Katherine Ellinghaus (Basingstoke: Palgrave Macmillan, 2009), pp. 99-115

- and Amanda Nettelbeck, 'Precarious Intimacies: Cross-Cultural Violence and Proximity in Settler Colonial Economies of the Pacific Rim', in Intimacies of Violence in the Settler Colony: Economies of Dispossession around the Pacific Rim, ed. by Penelope Edmonds and Amanda Nettelbeck (New York: Palgrave Macmillan, 2018), pp. 1-21

Eisler, William, The Furthest Shore: Images of Terra Australis from the Middle Ages to Captain Cook (Cambridge: Cambridge University Press, 1995)

Elleray, Michelle, Victorian Coral Islands of Empire, Mission, and the Boys' Adventure Novel (New York: Routledge, 2020)

Elliott, Jane, 'Was There a Convict Dandy? Convict Consumer Interests in Sydney, 1788-1815', Australian Historical Studies, 26 (1994), 373-92

Ellis, Markman, “That Singular and Wonderful Quadruped”: The Kangaroo as Historical Intangible Natural Heritage in the Eighteenth Century', in Intangible Natural Heritage: New Perspectives on Natural Objects, ed. by Eric Dorfman (New York: Routledge, 2012), pp. 56-87

Eperjesi, John, The Imperialist Imaginary: Visions of Asia and the Pacific in American Culture (Hanover: University Press of New England, 2005)

Erle, Sibylle, Laurie Garrison, Verity Hunt, and Phoebe Putnam, eds, Panoramas, 1787-1900: Texts and Contexts, 5 vols (London: Pickering and Chatto, 2013)

Etherington, Norman, 'Mission Station Melting Pots as a Factor in the Rise of South African Black Nationalism', The International Journal of African Historical Studies, 9.4 (1976), 592-605

Evans, Tanya, Fractured Families: Life on the Margins in Colonial New South Wales (Sydney: UNSW Press, 2015)

Fabian, Johannes, Language and Colonial Power: The Appropriation of Swahili in the Former Belgian Congo 1880-1938 (Cambridge: Cambridge University Press, 1986)

- Time and the Other: How Anthropology Makes Its Object, foreword Matti Bunzl (1983; repr. New York: Columbia University Press, 2002)

Farrell, Michael, 'The Colonial Baroque in Australia: On Drover Boab Texts, Wiradjuri Clubs, and Charlie Flannigan's Drawings', Criticism, 58.3 (2016), 409-31

- Writing Australian Unsettlement: Modes of Poetic Invention 1796-1945 (New York: Palgrave Macmillan, 2015)

Faulconbridge, James, and Allison Hui, 'Traces of a Mobile Field: Ten Years of Mobilities Research', Mobilities, 11.1 (2016), 1-14

Feldman, Jessica R., Gender on the Divide: The Dandy in Modernist Literature (Ithaca, NY: Cornell University Press, 1993)

Felski, Rita and Susan Stanford Friedman, 'Introduction', in Comparison: Theories, Approaches, Uses, ed. by Rita Felski and Susan Stanford Friedman (Baltimore: Johns Hopkins University Press, 2013), pp. 1-14

Festa, Lynn, Sentimental Figures of Empire in Eighteenth-Century Britain and France (Baltimore: Johns Hopkins University Press, 2006)

Fiddian-Qasmiyeh, Elena, and Patricia Daley, eds, Handbook of South-South Relations (Oxford: Routledge, 2018) 
Findlay, Elisabeth, 'Peddling Prejudice: A Series of Twelve Profile Portraits', Postcolonial Studies, 16.1 (2013), 2-27

Firmat, Gustavo Pérez, ed., Do the Americas Have a Common Literature? (Durham: Duke University Press, 1990)

Firth, Raymond, 'Proverbs in Native Life, with Special Reference to those of the Maori, II (Continued)', Folklore, 37.3 (1926), 245-70

Fletcher, B. H., 'Grose, Francis (1758-1814)', Australian Dictionary of National Biography, n.p., https://adb.anu.edu.au/biography/grose-francis-2130/text2701 (accessed 12 February 2020)

Ford, Lisa, and David A. Roberts, 'Expansion, 1820-1850', in The Cambridge History of Australia, ed. by Stuart Macintyre and Alison Bashford (Melbourne: Cambridge University Press, 2011), pp. 121-48

Ford, Thomas H., and Justin Clemens, 'Barron Field's Terra Nullius Operation', Australian Humanities Review, 65 (November 2019), 1-19

Forsdick, Charles, and Jennifer Yee, 'Towards a Postcolonial Nineteenth-Century', French Studies, 72.2 (2018), 161-75

Foster, Tol, 'Of One Blood: An Argument for Relations and Regionality in Native American Literary Studies', in Reasoning Together: The Native Critical Collective, ed. by Janice Acoose, Daniel Heath Justice, Christopher B. Teuton, and Craig Womack (Norman: University of Oklahoma Press, 2008), pp. 265-302

Fraser, Hilary, Stephanie Green, and Judith Johnston, Gender and the Victorian Periodical (Cambridge: Cambridge University Press, 2003)

Frost, Mark Ravinder, 'Emporium in imperio: Nanyang Networks and the Straits Chinese in Singapore, 1819-1914', Journal of Southeast Asian Studies, 36 (2005), 29-36

- 'Imperial Citizenship or Else: Liberal Ideals and the Indian Unmasking of Empire, 1890-1919', The Journal of Imperial and Commonwealth History, 46.5 (2018), $845-73$

— "Wider Opportunities": Religious Revival, Nationalist Awakening and the Global Dimension in Colombo, 1870-1920', Modern Asian Studies, 36.4 (2002), 937-67

Fulford, Tim, Romantic Indians: Native Americans, British Literature, and Transatlantic Culture 1756-1830 (Oxford: Oxford University Press, 2006)

- Debbie Lee, and Peter J. Kitson, eds, Literature, Science and Exploration in the Romantic Era (Cambridge: Cambridge University Press, 2004)

Fullagar, Kate, 'Introduction: The Atlantic World in the Antipodes', in The Atlantic World in the Antipodes: Effects and Transformations since the Eighteenth Century, ed. by Kate Fullagar (Newcastle upon Tyne: Cambridge Scholars Publishing, 2012), pp. xiii-xx

- The Warrior, the Voyager and the Artist: Three Lives in an Age of Empire (Yale: Yale University Press, 2020)

Fuller, Jennifer, 'Terror in the South Seas: Violence, Relationships, and the Works of Louis Becke', Australasian Journal of Victorian Studies, 20.2 (2015), 42-57

Gammage, Bill, The Biggest Estate on Earth: How Aborigines Made Australia (Sydney: Allen and Unwin, 2011)

Gardner, Jared, The Rise and Fall of Early American Magazine Culture (Urbana: University of Illinois Press, 2012)

Garvey, Nathan, The Celebrated George Barrington: A Spurious Author, the Book Trade, and Botany Bay (Potts Point: Hordern House, 2008) 
Gascoigne, John, 'Cross-Cultural Knowledge Exchange in the Age of the Enlightenment', in Indigenous Intermediaries, ed. by Shino Konishi, Maria Nugent, and Tiffany Shellam (Canberra: Australian National University Press, 2015), pp. 131-46

Gelder, Ken, 'The Postcolonial Gothic', in The Cambridge Companion to the Modern Gothic, ed. by Jerrold E. Hogle (Cambridge: Cambridge University Press, 2014), pp. 191-207

Gibson, Ross, 'Event-Grammar: The Language Notebooks of William Dawes', Meanjin, 68.2 (2009), n.p., https://meanjin.com.au/essays/event-grammar-thelanguage-notebooks-of-william-dawes/ (accessed 1 February 2020)

- 26 Views of the Starburst World: William Dawes at Sydney Cove 1788-91 (Crawley: University of Western Australia Publishing, 2012)

Gikandi, Simon, Maps of Englishness: Writing Identity in the Culture of Colonialism (New York: Columbia University Press, 1996)

- 'Realism, Romance, and the Problem of African Literature', Modern Language Quarterly, 73.3 (2012), 309-29

- Slavery and the Culture of Taste (Princeton: Princeton University Press, 2011)

Giles, Paul, Antipodean America: Australasia and the Constitution of U. S. Literature (Oxford: Oxford University Press, 2013)

- Virtual Americas: Transnational Fictions and the Transatlantic Imaginary (Durham and London: Duke University Press, 2002)

Gilling, Bryan, 'Raupatu: the Punitive Confiscation of Maori Land in the 1860s', in Raupatu: The Confiscation of Maori Land, ed. by Richard Boast and Richard S. Hill (Wellington: Victoria University Press, 2009), pp. 13-30

Gillis, John R., 'The Blue Humanities', Humanities, 34.3 (2013), n.p., www.neh.gov/ humanities/2013/mayjune/feature/the-blue-humanities (accessed 1 February 2020)

Gilmour, Joanna, Elegance in Exile: Portrait Drawings from Colonial Australia (Canberra: National Portrait Gallery, 2012)

Gilmour, Rachael, Grammars of Colonialism: Representing Languages in Colonial South Africa (Basingstoke: Palgrave Macmillan, 2006)

Gilroy, Paul, The Black Atlantic: Modernity and Double Consciousness (Cambridge, MA: Harvard University Press, 1993)

Gissibl, Bernhard, 'The Conservation of Luxury: Safari Hunting and the Consumption of Wildlife in Twentieth-Century East Africa', in Luxury in Global Perspective: Objects and Practices, 1600-2000, ed. by Bernd-Stefan Grewe and Karin Hofmeester (Cambridge: Cambridge University Press, 2016)

Goh, Daniel, 'Elite Schools, Postcolonial Chineseness and Hegemonic Masculinities in Singapore', British Journal of Sociology of Education, 36.1 (2005), 137-55

- 'Unofficial Contentions: The Postcoloniality of Straits Chinese Political Discourse in the Straits Chinese Legislative Council', Journal of Southeast Asian Studies, 41.3 (2010), 483-507

Golder, Hilary, High and Responsible Office: A History of the NSW Magistracy (Sydney: Sydney University Press, 1991)

Goldie, Matthew Boyd, The Idea of the Antipodes: Place, People and Voices (London and New York: Routledge, 2010)

Goldie, Terry, Fear and Temptation: The Image of the Indigene in Canadian, Australian, and New Zealand Literatures (Montreal and Kingston: McGill-Queens University Press, 1989)

González, Natalicio, 'The Paraguayan People and Their Natural Tendencies', in The Paraguay Reader: History, Culture, Politics, ed. by Peter Lambert and Andrew Nickson (Durham: Duke University Press, 2013), pp. 178-83 
Goodlad, Lauren M. E., 'Cosmopolitanism’s Actually Existing Beyond; Toward A Victorian Geopolitical Aesthetic', Victorian Literature and Culture, 38 (2010), 399-411

-- The Victorian Geopolitical Aesthetic (Oxford: Oxford University Press, 2015)

Goswami, Manu, 'Autonomy and Comparability: Notes on the Anticolonial and the Postcolonial', boundary 2, 32.2 (2005), 201-25

- 'Imaginary Futures and Colonial Internationalisms', The American Historical Review, 117.5 (2012), 1461-85

Gottlieb, Evan, Romantic Globalism: British Literature and the Modern World Order, 1750-1830 (Columbus: Ohio State University Press, 2014)

Graham, Mary, 'Some Thoughts about the Philosophical Underpinnings of Aboriginal Worldviews', Australian Humanities Review, 45 (2008), 181-94

Griffiths, Devin, The Age of Analogy: Science and Literature Between the Darwins (Baltimore: Johns Hopkins University Press, 2016)

- and Deanna Kriesel, 'Introduction: Open Ecologies', Victorian Literature and Culture, 48.1 (2020), 1-28

Griffiths, Phil, “"This is a British Colony”: The Ruling-Class Politics of the Seafarer's Strike, 1878-79', Labour History, 105 (2013), 131-51

Griffiths, Tom, 'Remembering', in Christine Hansen and Tom Griffiths, Living With Fire: People, Nature and History in Steels Creek (Collingwood: CSIRO Publishing, 2012), pp. 159-85

Grimshaw, Patricia, Marilyn Lake, Ann McGrath, and Marian Quartly, Creating a Nation, 1788-1900 (Ringwood: Penguin Book Australia, 1994)

Groth, Helen, 'Mediating Popular Fictions: From the Magic Lantern to the Cinematograph', in New Directions in Popular Fiction: Genre, Distribution, Reproduction, ed. by Ken Gelder (London: Palgrave Macmillan, 2016), pp. 287-308

Gruber, Jacob W., 'Ethnographic Salvage and the Shaping of Anthropology', American Anthropologist, 72.6 (1970), 1289-99

Guy, Jeff, Theophilus Shepstone and the Forging of Natal (Pietermaritzburg: University of KwaZulu-Natal Press, 2013)

Hackforth-Jones, Jocelyn, Augustus Earle: Travel Artist (Canberra: National Library of Australia, 1980)

- Augustus Earle: Travel Artist: Paintings and Drawings in the Rex Nan Kivell Collection National Library of Australia (Martinborough: Alister Taylor, 1980)

Hadot, Pierre, The Veil of Isis: An Essay on the History of the Idea of Nature (Cambridge, MA: The Belknap Press, 2006)

Halford, James, 'Southern Conversations: J. M. Coetzee in Buenos Aires', Sydney Review of Books (28 February 2017), n.p., https://sydneyreviewofbooks.com/ essay/southern-conversations-j-m-coetzee-in-buenos-aires/ (accessed 1 May 2020)

Hall, Catherine, 'Macaulay's Nation,' Victorian Studies, 51.3 (2009), 505-23

Hall, Stuart, 'Gramsci's Relevance for the Study of Race and Ethnicity', Journal of Communication Inquiry, 10.2 (1986), 5-27

Hannabuss, Stuart, 'Islands as Metaphors', Universities Quarterly, 38.1 (1983/4), $70-82$

Hansen, David, “'Another man's understanding”: Settler Images of Aboriginal People', in Colony: Australia 1770-1861 / Frontier Wars, ed. by Cathy Leahy and Judith Ryan (Melbourne: National Gallery of Victoria, 2018), pp. 108-19

Hanson, Clare, Short Stories and Short Fiction 1880-1945 (London: Macmillan, 1985) 
Harootunian, Harry, 'Remembering the Historical Present', Critical Inquiry, 33.3 (2007), 471-94

Harris, Margaret, 'The Antipodean Anatomy of Victorian Studies', AUMLA: Journal of the Australasian Universities Modern Language Association, 100 (2003), 61-72

Harris, Wendell V., British Short Fiction in the Nineteenth Century (Detroit: Wayne State University Press, 1979)

Harrison, Robert Pogue, Forests: The Shadow of Civilization (Chicago: University of Chicago Press, 1992)

Harter, Eugene C., The Lost Colony of the Confederacy (Oxford, MS: University of Mississippi Press, 1985)

Hau'ofa, Epeli, 'Epilogue: Pasts to Remember', in Remembrance of Pacific Pasts: An Invitation to Remake History, ed. by Robert Borofsky (Honolulu: University of Hawai'i Press, 2000), pp. 453-71

- 'Our Sea of Islands', in A New Oceania: Rediscovering Our Sea of Islands, ed. by Eric Waddell, Vijay Naidu, and Epeli Hau'ofa (Suva: University of the South Pacific, 1993), pp. 2-17

- We Are the Ocean (Honolulu: University of Hawai'i Press, 2008)

Hayot, Eric, The Hypothetical Mandarin: Sympathy, Modernity, and Chinese Pain (Oxford: Oxford University Press, 2009)

- On Literary Worlds (Oxford: Oxford University Press, 2012)

Heidegger, Martin, 'The Age of the World Picture', in Off the Beaten Track, trans. and ed. by Julian Young and Kenneth Hayes (Cambridge: Cambridge University Press, 2002), pp. 1-56

- 'On the Origin of the Work of Art', in Basic Writings, ed. by David Farrell Krell (New York: Harper Collins, 2008), pp. 143-212

Herbert, Christopher, 'Epilogue: Ethnography and Evolution', Victorian Studies, 41.3 (1998), 485-94

Hessell, Nikki, Romantic Literature and the Colonised World: Lessons from Indigenous Translations (Basingstoke: Palgrave Macmillan, 2018)

Hewett, Dorothy, 'The Journey of Henry Lawson', Australian Left Review, 7 (1967), 28-34

Hiatt, Alfred, 'Terra Australis and the Idea of the Antipodes', in European Perceptions of Terra Australis, ed. by Anne M. Scott, Alfred Hiatt, Claire McIlroy, and Christopher Wortham (London and New York: Routledge, 2016), pp. 9-44

- Terra Incognita: Mapping the Antipodes Before 1600 (Chicago: University of Chicago Press, 2008)

Hickford, Mark, 'Strands from the Afterlife of Confiscation: Property Rights, Constitutional Histories and the Political Incorporation of Maori, 1920s', in Raupatu: The Confiscation of Maori Land, ed. by Richard Boast and Richard S. Hill (Wellington: Victoria University Press, 2009), pp. 169-204

Higgins, David, 'Writing to Colonial Australia: Barron Field and Charles Lamb', Nineteenth-Century Contexts, 32.3 (2010), 219-33

Hill, Peter, Utopia and Civilisation in the Arab Nahda (Cambridge: Cambridge University Press, 2020)

Hill, Richard S., Enthroning 'Iustice Above Might'? The Sim Commission, Tainui and the Crown (Wellington: Department of Justice, 1989)

- Maori and the State: Crown-Maori Relations in New Zealand/ Aotearoa, 19502000 (Wellington: Victoria University Press, 2009) 
Hitchcock, Peter, The Long Space: Transnationalism and Postcolonial Form (Stanford: Stanford University Press, 2010)

Hoagwood, Terence Allan and Kathryn Ledbetter, 'Colour'd Shadows': Contexts in Publishing, Printing, and Reading Nineteenth-Century British Women Writers (Basingstoke: Palgrave Macmillan, 2005)

Hobson, John M., The Eastern Origins of Western Civilisation (Cambridge: Cambridge University Press, 2004)

Hofmeyr, Isabel, 'The Black Atlantic Meets the Indian Ocean: Forging New Paradigms of Transnationalism for the Global South - Literary and Cultural Perspectives', Social Dynamics: A Journal of African Studies, 33.7 (2007), 3-32

- Gandhi's Printing Press: Experiments in Slow Reading (Cambridge, MA: Harvard University Press, 2013)

- The Portable Bunyan: A Transnational History of The Pilgrim's Progress (Princeton: Princeton University Press, 2004)

- 'Southern by Degrees: Islands and Empires in the South Atlantic, the Indian Ocean, and the Subantartic World', in The Global South Atlantic, ed. by Kerry Bystrom and Joseph R. Slaughter (New York: Fordham University Press, 2018), pp. 81-96

— 'Universalizing the Indian Ocean', PMLA, 125.3 (2010), 721-9

Holden, Philip, 'The Beginnings of "Asian Modernity" in Singapore: A Straits Chinese Body Project', Common/Plural, 7.1 (1999), 59-78

- 'Between Modernization and Modernism: Community and Contradiction in the Paracolonial Short Story’, Philippine Studies, 55.3 (2007), 319-43

— 'China Men: Writing the British Nation in Malaya', SPAN, 38 (1994), 75-85

- 'Colonial Fiction, Hybrid Lives: Early Singaporean Fiction in The Straits Chinese Magazine', Journal of Commonwealth Literature, 33.1 (1998), 85-97

- 'Communities and Conceptual Limits: Exploring Malaysian Literature in English', Asiatic, 3.2 (2009), 54-68

- 'Dissonant Voices: Straits Chinese and the Appropriation of Travel Writing', Studies in Travel Writing, 2.1 (1998), 181-9

- 'The Littoral and the Literary: Making Moral Communities in the Straits Settlements and the Gold Coast in the Late Nineteenth and Early Twentieth Centuries', in Singapore in Global Context, ed. by Derek Heng and Syed Muhd Khairudin Aljunied (Amsterdam: Amsterdam University Press, 2011), pp. 89-110

Holmes, Richard, The Age of Wonder: How the Romantic Generation Discovered the Beauty and Terror of Science (London: Harper Press, 2009)

Horrocks, Ingrid, 'A World of Waters: Imagining, Voyaging, Entanglement', in A History of New Zealand Literature, ed. by Mark Williams (Cambridge: Cambridge University Press, 2016), pp. 17-30

Hunter, Lani Kavika, 'Spirits of New Zealand: Early Pakeha Writers on Maori' (unpublished doctoral thesis, Auckland University, 2004)

Huston, James L., The Panic of 1857 and The Coming of the Civil War (Baton Rouge: Louisiana State University Press, 1987)

Iqani, Mehita, and Fernando Resende, Media and the Global South: Narrative Territorialities, Cross-Cultural Currents (London: Routledge, 2019)

Irvine, Judith T., 'The Family Romance of Colonial Linguistics: Gender and Family in Nineteenth-Century Representations of African Languages', Pragmatics, 5.2 (1995), 139-53

Ivison, Duncan, 'Non-Cosmopolitan Universalism: On Armitage's Foundations of International Political Thought', History of European Ideas, 41.1 (2015), 78-88 
Jackson, Shona N., Creole Indigeneity: Between Myth and Nation in the Colonial Caribbean (Minneapolis: University of Minnesota Press, 2012)

Jacob, Christian, The Sovereign Map: Theoretical Approaches in Cartography throughout History, trans. by Tom Conley (Chicago: University of Chicago Press, 2006)

Jaffer, Aaron, Lascars and Indian Ocean Seafaring, 1780-1860: Shipboard Life, Unrest and Mutiny (Woodbridge: Boydell, 2015)

Johannesburg Workshop in Theory and Criticism, n.p., www.jwtc.org.za (accessed 26 June 2019)

Johnston, Anna, “"The Aboriginal Mother”: Poetry and Politics', in Remembering the Myall Creek Massacre, ed. by Jane Lydon and Lyndall Ryan (Sydney: NewSouth, 2018), pp. 68-84

- Missionary Writing and Empire, 1800-1860 (Cambridge: Cambridge University Press, 2003)

- 'Mrs Milson's Wordlist: Eliza Hamilton Dunlop and the Intimacy of Linguistic Work', in Intimacies of Violence in the Settler Colony: Economies of Dispossession around the Pacific Rim, ed. by Penelope Edmonds and Amanda Nettelbeck (Cham: Palgrave Macmillan, 2018), pp. 225-47

- The Paper War: Morality, Print Culture, and Power in Colonial New South Wales (Crawley: University of Western Australia Press, 2011)

- and Elizabeth Webby, eds, Eliza Hamilton Dunlop: Writing from the Colonial Frontier (Sydney: Sydney University Press, 2021)

Jolly, Margaret, 'Imagining Oceania: Indigenous and Foreign Representations of a Sea of Islands', The Contemporary Pacific, 19.2 (2007), 508-45

- 'The South in Southern Theory: Antipodean Reflections on the Pacific', Australian Humanities Review, 44 (2008), n.p., http://australianhumanitiesreview.org/2008/ 03/01/the-south-in-southern-theory-antipodean-reflections-on-the-pacific/ (accessed 26 June 2019)

Jose, Nicholas, 'Introduction', in Macquarie PEN Anthology of Australian Literature, ed. by Nicholas Jose (Sydney: Allen \& Unwin, 2009), pp. 1-2

Joyce, Patrick D., The Rule of Freedom: Liberalism and the Modern City (London and New York: Verso, 2003)

Karis, Thomas, and Gwendolen Carter, eds, From Protest to Challenge, Vol. 1: A Documentary History of African Politics in South Africa, 1882-1964: Protest and Hope, 1882-1934 (1972; repr. Stanford: Hoover Institution Press, 2003)

Karskens, Grace, The Colony: A History of Early Sydney (Sydney: Allen \& Unwin, 2009)

- 'Red Coat, Blue Jacket, Black Skin: Aboriginal Men and Clothing in early New South Wales', Aboriginal History, 35 (2011), 1-36

Kaul, Chandrika, Reporting the Raj: The British Press and India, c. 1880-1922 (Manchester: Manchester University Press, 2003)

Keegan, Timothy, Colonial South Africa and the Origins of the Racial Order (Cape Town: David Philip, 1996)

Keneally, Thomas, Australians: Eureka to the Diggers (Sydney: Allen \& Unwin, 2011)

Keynes, Richard, The Beagle Record (Cambridge: Cambridge University Press, 2012)

Khor, Neil, 'Imperial Cosmopolitan Malaya: A Study of Realist Fiction in the Straits Chinese Magazine', JMBRAS, 81.1 (2008), 27-47 
- 'Malacca's Straits Chinese Anglophone Poets and their Experience of Malaysian Nationalism', Archipel, 76 (2008), 127-49

Klancher, Jon, The Making of English Reading Audiences, 1790-1832 (Madison: University of Wisconsin Press, 1983)

Kleinpenning, Jan M. G., Rural Paraguay, 1870-1963: A Geography of Progress, Plunder and Poverty, 2 vols (Madrid: Iberoamericana Vervuert, 2009)

Koditschek, Theodore, Liberalism, Imperialism, and the Historical Imagination: Nineteenth-Century Visions of a Greater Britain (Cambridge: Cambridge University Press, 2011)

Kōhere, Rarawa, 'Kohere, Mokena', in Dictionary of New Zealand Biography, 5 vols (1990-2000) I (1990), n.p., https://teara.govt.nz/en/biographies/1k15/ kohere-mokena (accessed 2 October 2017)

- 'Tāwakewake: An Historical Case Study and Situational Analysis of Ngāti Ruawaipu Leadership' (unpublished doctoral thesis, Massey University, 2005)

Konishi, Shino, 'First Nations Scholars, Settler Colonial Studies, and Indigenous History', Australian Historical Studies, 50 (2019), 1-20

- Maria Nugent, and Tiffany Shellam, eds, Indigenous Intermediaries: New Perspectives on Exploration Archives (Canberra: Australian National University Press, 2015)

Korte, Barbara, The Short Story in Britain: A Historical Sketch and Anthology (Tübingen: A. Francke Verlag Tübingen und Basel, 2003)

Kranidis, Rita S., The Victorian Spinster and Colonial Emigration: Contested Subjects (Basingstoke: Macmillan, 1999)

Krishnan, Sanjay, 'History and the Work of Literature in the Periphery', Novel: A Forum on Fiction, 42 (2009), 483-9

- 'Reading Globalization from the Margin: The Case of Abdullah Munshi', Representations, 99.1 (2007), 40-73

Kyle, Noeline J., “"Delicate health ... interesting condition ...”: Eliza Darling, Pregnancy and Philanthropy in Early New South Wales', History of Education, 24 (1995), 25-43.

Laband, John, The Eight Zulu Kings (Johannesburg: Jonathan Ball, 2018)

- and John Wright, King Cetshwayo kaMpande (Durban and Ulundi: Shuter and Shooter, KwaZulu Monuments Council, 1980)

Lake, Marilyn, 'White Man's Country: The Transnational History of a National Project', Australian Historical Studies, 34.122 (2003), 346-63

Lamb, Jonathan, Vanessa Smith, and Nicholas Thomas, 'Introduction', in Exploration and Exchange: A South Seas Anthology, 1680-1900, ed. by Jonathan Lamb, Vanessa Smith, and Nicholas Thomas (Chicago: University of Chicago Press, 2000), pp. xiii-xxv

Lange, Raeburn, Island Ministers: Indigenous Leadership in Nineteenth Century Pacific Islands Christianity (Canberra: Pandanus Press, 2006)

Langton, Marcia, Well, I Heard it on the Radio and Saw it on the Television (North Sydney: Australian Film Commission, 1993)

Law, Graham, 'Savouring of the Australian Soil? On the Sources and Affiliations of Colonial Newspaper Fiction', Victorian Periodicals Review, 37.4 (2004), 75-97

Lawson, Elizabeth, 'Louisa Atkinson: The Distant Sound of Native Voices', Occasional Paper No. 15 (English Department University College, Australian Defence Force Academy, Canberra, 1989) 
— 'Louisa Atkinson: Writings on Aboriginal Land Ownership', Margin, 21 (1989), 15-20.

- The Natural Art of Louisa Atkinson (Sydney: State Library of New South Wales Press, 1995)

Lazarus, Neil, The Postcolonial Unconscious (Cambridge: Cambridge University Press, 2011)

Legassick, Martin, 'The Frontier Tradition in South African Historiography', Collected Seminar Papers, Institute of Commonwealth Studies, 12 (1972), 1-33

Levander, Caroline, and Walter Mignolo, 'Introduction: The Global South and World Dis/Order', The Global South, 5.1 (2011), 1-11

Lifshey, Adam, Specters of Conquest: Indigenous Absence in Transatlantic Literatures (New York: Fordham University Press, 2010)

Lineham, Peter, Sunday Best: How the Church Shaped New Zealand and New Zealand Shaped the Church (Auckland: Massey University Press, 2017)

Lionnet, François, and Shu-mei Shih, eds, Minor Transnationalism (Durham: Duke University Press, 2005)

Loader, Arini, 'Early Māori Literature: The Writing of Hajaraia Kiharoa', in A History of New Zealand Literature, ed. by Mark Williams (Cambridge: Cambridge University Press, 2016), pp. 31-43

Lootens, Tricia, 'Hemans and Home: Victorianism, Feminine "Internal Enemies", and the Domestication of National Identity', PMLA, 109.2 (1994), 238-53

Lopez, Barry, Arctic Dreams (1986; repr. London: Vintage, 2014)

Lott, Eric, Love and Theft: Blackface Minstrelsy and the American Working Class (1993; repr. Oxford: Oxford University Press, 2013)

Lowe, Gail, 'Book History', in The Oxford History of the Novel in English, Volume 9: The World Novel to 1950, ed. by Ralph Crane, Jane Stafford, and Mark Williams (Oxford: Oxford University Press, 2016), pp. 11-28

Lydon, Jane, and Lyndall Ryan, eds, Remembering the Myall Creek Massacre (Sydney: NewSouth Publishing, 2018)

Macdonald, Charlotte, 'Beyond the Realm: The Loss of Culture as the Colonial Condition', Journal of New Zealand Studies, 12 (2011), 1-12

Mackenzie, John M., 'Lakes, Rivers and Oceans: Technology, Ethnicity and the Shipping of Empire in the Late Nineteenth Century', in Maritime Empires: British Imperial Maritime Trade in the Nineteenth Century, ed. by David Killingray, Margarette Lincoln, and Nigel Rigby (Woodbridge: Boydell in association with National Maritime Museum, 2004), pp. 111-27

Macoun, Alissa, and Elizabeth Strakosch, 'The Ethical Demands of Settler Colonial Theory', Settler Colonial Studies, 3.4 (2013), 426-43

Macqueen, Ian M., Black Consciousness and Progressive Movements under Apartheid (Pietermaritzburg: University of KwaZulu-Natal Press, 2018)

Mahuta, Robert Te Kotahi, 'Whaikoorero: A Study of Formal Maori Speech' (unpublished master's thesis, University of Auckland, 1974)

Majeed, Javed, 'Literary Modernity in South Asia', in India and the British Empire, ed. by Douglas Peers and Nandini Gooptu (Oxford: Oxford University Press, 2012), pp. 262-83

Mandler, Peter, 'The Problem with Cultural History', Cultural and Social History, 1 (2004), 94-117

Marcus, Sharon, 'Same Difference? Transnationalism, Comparative Literature, and Victorian Studies', Victorian Studies, 45.4 (2003), 677-86 
Maretu, Cannibals and Converts: Radical Change in the Cook Islands, trans. and ed. by Marjorie Tua'inekore Crocombe (Suva: University of the South Pacific, 1983)

Martin, Meredith, “'Imperfectly Civilized”: Ballads, Nations, and Histories of Form', ELH, 82.2 (2015), 345-63

Martin, Susan K., “"Tragic ring-barked forests” and the "Wicked Wood”: Haunting Environmental Anxiety in Late Nineteenth-Century Australian Literature', in Victorian Environmental Nightmares, ed. by Laurence W. Mazzeno and Ronald D. Morrison (London: Palgrave Macmillan, 2019), pp. 121-43

Martin, Tony, ed., African Fundamentalism: A Literary and Cultural Anthology of Garvey's Harlem Renaissance (Dover: The Majority Press, 1991)

Masilela, Ntongela, 'Vernacular Press', in Encyclopedia of African Literature, ed. by Simon Gikandi (London: Routledge, 2003), pp. 547-54

Massey, Doreen, For Space (London: Sage, 2005)

Masuzawa, Tomoko, The Invention of World Religions: Or, How European Universalism Was Preserved in the Language of Pluralism (Chicago: University of Chicago Press, 2005)

Matsuda, Matt K., Pacific Worlds: A History of Seas, Peoples, and Cultures (Cambridge: Cambridge University Press, 2012)

Maynard, Margaret, Fashioned from Penury: Dress as Cultural Practice in Colonial Australia (Cambridge: Cambridge University Press, 1994)

McCann, Andrew, 'Romanticism, Nationalism and the Myth of the Popular in William Lane's The Workingman's Paradise', Journal of Australian Studies, 25.70 (2001), 1-12

McCormick, E. H., 'Introduction', in Narrative of a Residence in New Zealand; Journal of a Residence in Tristan Da Cunha, ed. by E. H. McCormick (1832; repr. Oxford: Clarendon, 1966), pp. 1-46

McKenzie, Kirsten, "Franklins of the Cape": The "South African Commercial Advertiser" and the Creation of a Colonial Public Sphere, 1824-1854', Kronos, 25 (1998), 88-102

McLachlan, Noel, 'Introduction', in James Hardy Vaux, The Memoirs of James Hardy Vaux, ed. by Noel McLachlan (London: Heinemann, 1964), pp. xv-lxxxii

McQueen, Humphrey, A New Britannia: An Argument Concerning the Social Origins of Australian Radicalism and Nationalism (1970; repr. New York: Penguin, 1980)

Mead, Hirini Moko, Tikanga Māori: Living By Māori Values (Wellington: Huia Publishers, 2003)

Mead, Philip, 'Nation, Literature, Location', in The Cambridge History of Australian Literature, ed. by Peter Pierce (Cambridge: Cambridge University Press, 2011), pp. 549-67

Means, Russell, 'The Same Old Song', in Marxism and Native Americans, ed. by Ward Churchill (Boston: South End Press, 1992), pp. 19-34

Mehta, Uday Singh, Liberalism and Empire: A Study in Nineteenth-Century British Liberal Thought (Chicago: University of Chicago Press, 1999)

Menezes, Mary Noel, The Amerindians in Guyana, 1803-73: A Documentary History (London: Frank Cass, 1979)

— British Policy towards the Amerindians in British Guiana, 1803-1873 (Georgetown: Caribbean Press, 2011)

Merleau-Ponty, Maurice, Phenomenology of Perception, trans. by Colin Smith (London: Routledge and Kegan Paul, 1962) 
Mignolo, Walter D., 'The Global South And World Dis/order', Journal of Anthropological Research, 67 (2011), 165-88

- Local Histories/Global Designs: Coloniality, Subaltern Knowledges, and Border Designs (Princeton: Princeton University Press, 2000)

- 'On Comparison: Who is Comparing What and Why?', in Comparison: Theories, Approaches, Uses, ed. by Rita Felski and Susan Stanford Friedman (Baltimore: Johns Hopkins University Press, 2013), pp. 99-119

Milliss, Roger, Waterloo Creek: The Australia Day Massacre of 1838, George Gipps and the British Conquest of New South Wales (Ringwood: McPhee Gribble, 1992)

Mitchell, W. J. T., 'Imperial Landscapes', in Landscape and Power, 2nd edn (Chicago: University of Chicago Press, 2002), pp. 5-34

Mkhize, Khwezi, 'Empire Unbound: Imperial Liberalism, Race and Diaspora in the Making of South Africa' (unpublished doctoral thesis, University of Pennsylvania, 2015)

Monin, Paul, 'Maori Encounters and Colonial Capitalism', in The New Oxford History of New Zealand, ed. by Giselle Byrnes (Melbourne: Oxford University Press, 2009), pp. 125-46

Moore, Grace, "'Raising high its thousand forked tongues”: Campfires, Bushfires, and Portable Domesticity in Nineteenth-Century Australia', 19: Interdisciplinary Studies in the Long Nineteenth Century, 26 (2018), n.p., https://doi.org/10.16995/ ntn.807 (accessed 19 November 2019)

- 'Surviving Black Thursday: The Great Bushfire of 1851', in Victorian Settler Narratives: Emigrants, Cosmopolitans and Returnees in Nineteenth-Century Literature, ed. by Tamara S. Wagner (London and New York: Routledge, 2016), pp. 129-39

Moraru, Christian, “World”, "Globe”, "Planet”: Comparative Literature, Planetary Studies, and Cultural Debt after the Global Turn', n.p., https://stateofthediscipline. acla.org/entry/"world"-"globe"-"planet"-comparative-literature-planetary-studies-and-cultural-debt-after (accessed 2 March 2020)

Moreton-Robinson, Aileen, ed., Critical Indigenous Studies: Engagements in First World Locations (Tucson: University of Arizona Press, 2016)

Moretti, Franco, 'Conjectures on World Literature', New Left Review, 1 (2000), 54-68

Morieux, Renaud, Clare Anderson, Jonathan Lamb, David Armitage, Alison Bashford, and Sujit Sivasundaram, 'Oceanic Histories: A Roundtable', Journal of Colonialism and Colonial History, 19.2 (2018), n.p., https://muse.jhu.edu/article/700167 (accessed 1 February 2020)

Mosquera, Geraldo, 'Some Problems in Transcultural Curating', in Global Visions: Towards a New Internationalism in the Visual Arts, ed. by Jean Fisher (London: Kala Press, 1994), pp. 133-9

Mostert, Noel, Frontiers: The Epic of South Africa's Creation and the Tragedy of the Xhosa People (New York: Knopf, 1992)

Motion, Andrew, Wainewright the Poisoner (New York: Alfred A. Knopf, 2000)

Moura, Sabrina, ed., Southern Panoramas: Perspectives for Other Geographies of Thought (Rio de Janeiro: Videobrasil, 2015)

Muckerjee, Upamanyu Pablo, 'Introduction: Victorian World Literature', The Yearbook of English Studies, 41.2 (2011), 1-19

Muecke, Stephen, 'Cultural Studies' Networking Strategies in the South', Australian Humanities Review, 44 (2008), 39-51 
Müller, Gesine, Jorge J. Locane, and Benjamin Loy, 'Introduction', in Re-Mapping World Literature: Writing, Book Markets and Epistemologies between Latin America and the Global South, ed. by Gesine Müller, Jorge J. Locane, and Benjamin Loy (Boston: De Gruyter, 2018), pp. 1-12

Murphy, Kevin, and Sally O'Driscoll, Studies in Ephemera: Text and Image in Eighteenth-Century Print (Lewisburg: Bucknell University Press, 2013)

Murray, Kevin, 'Keys to the South', Australian Humanities Review, 44 (2008), 23-38

Murray-Oliver, Anthony, Augustus Earle in New Zealand (Christchurch: Whitcombe \& Tombs, 1968)

Muthyala, John, Reworlding America: Myth, History and Narrative (Athens: Ohio University Press, 2006)

Myers, Janet C., Antipodal England: Emigration and Portable Domesticity in the Victorian Imagination (New York: State University of New York Press, 2009)

Mzamane, Mbulelo Vizikhungo, 'Colonial and Imperial Themes in South African Literature, 1820-1930', The Yearbook of English Studies, 13 (1983), 181-95

Naidu, Sam, 'The Emergence of the South African Farm Crime Novel: Socio-Historical Crimes, Personal Crimes, and the Figure of the Dog', English in Africa, 43.2 (2016), 9-38

Nathan, Hans, Dan Emmett and the Rise of Early Negro Minstrelsy (Norman: University of Oklahoma Press, 1962)

Nettelbeck, Amanda, Indigenous Rights and Colonial Subjecthood: Protection and Reform in the Nineteenth-Century British Empire (Cambridge: Cambridge University Press, 2019)

Neville, Richard, Mr J.W. Lewin, Painter and Naturalist (Sydney: NewSouth Publishing and National Library of Australia, 2012)

Newmeyer, Frederick J., The Politics of Linguistics (Chicago: University of Chicago Press, 1986)

Newton-King, Susan, Masters and Servants on the Cape Eastern Frontier, 1760-1803 (Cambridge: Cambridge University Press, 1999)

Nicholson, Ian Hawkins, Log of Logs: A Catalogue of Logs, Journals, Shipboard Diaries, Letters, and All Forms of Voyage Narratives, 1788 to 1988, for Australia and New Zealand and Surrounding Oceans (Nambour: The Author jointly with the Australian Association for Maritime History, 1990)

Nishime, Leilani, and Kim D. Hester Williams, 'Introduction: Why Racial Ecologies', in Racial Ecologies, ed. by Leilani Nishime and Kim D. Hester Williams (Washington: University of Washington Press, 2018), pp. 3-18

Nixon, Rob, Slow Violence and the Environmentalism of the Poor (Cambridge, MA: Harvard University Press, 2011)

Nugent, Maria, 'Jacky Jacky and the Politics of Aboriginal Testimony', in Indigenous Intermediaries, ed. by Shino Konishi, Maria Nugent, and Tiffany Shelam (Canberra: Australian National University Press, 2015), pp. 67-84

Ogburn, Miles, Indian Ink: Script and Print in the Making of the East India Company (Chicago: Chicago University Press, 2007)

O'Leary, John, Savage Songs and Wild Romances: Settler Poetry and the Indigene, 1830-1880 (Amsterdam: Rodopi, 2011)

Olsen, Penny, Louisa Atkinson's Nature Notes (Canberra: National Library of Australia, 2015)

O’Malley, Vincent, The Meeting Place: Māori and Pākehā Encounters, 1642-1840 (Auckland: Auckland University Press, 2012) 
Omar, Hussein, 'Arabic Thought in the Liberal Cage', in Islam After Liberalism, ed. by Faisal Devji and Zaheer Kazmi (Oxford: Oxford University Press, 2005), pp. 17-45

Opland, Jeff, 'Nineteenth-Century Xhosa Literature', Kronos, 30 (2004), 22-46

Orange, Claudia, The Treaty of Waitangi, 2nd edn (Wellington: Bridget Williams Books, 2011)

Orel, Harold, The Victorian Short Story: Development and Triumph of a Literary Genre (Cambridge: Cambridge University Press, 1986)

Otto, Peter, Multiplying Worlds: Romanticism, Modernity, and the Emergence of Virtual Reality (Oxford: Oxford University Press, 2011)

Page, Stephen, Patyegarang (San Francisco: Kanopy Streaming, 2015)

Parr, C. J., 'A Missionary Library: Printed Attempts to Instruct the Maori, 1815-1845', Journal of the Polynesian Society, 70 (1961), 436-40

Parsons, Neil, King Khama, Emperor Joe, and the Great White Queen: Victorian Britain through African Eyes (Chicago and London: University of Chicago Press, 1998)

Paterson, Lachy, Colonial Discourses: Niupepa Māori, 1855-1863 (Dunedin: Otago University Press, 2006)

Pawson, Eric, and Tom Brooking, eds, Making a New Land: Environmental Histories of New Zealand, new edn (Dunedin: Otago University Press, 2013)

Peach, Annette, Portraits of Byron (London: The Walpole Society, 2000)

- 'Wainewright, Thomas Griffiths [pseuds. Janus Weathercock, Cornelius van Vinkbooms]', Oxford Dictionary of National Biography, n.p., https://doi.org/10.1093/ ref:odnb/28403 (accessed 1 February 2020)

Pennycook, Alastair, English and the Discourse of Colonialism (London and New York: Routledge, 1998)

Perkins, T. M., 'Atkinson, James: 1795-1834', The Australian Dictionary of National Biography, n.p., http://adb.anu.edu.au/biography/atkinson-james-1726 (accessed 30 November 2019)

Perry, Adele, Colonial Relations: The Douglas-Connolly Family and the NineteenthCentury Imperial World (Cambridge: Cambridge University Press, 2015)

Piesse, Jude, British Settler Emigration in Print, 1832-1877 (Oxford: Oxford University Press, 2016)

Pierce, Peter, ed., The Cambridge History of Australian Literature (Cambridge: Cambridge University Press, 2009)

Plumb, Christopher, The Georgian Menagerie: Exotic Animals in Eighteenth-Century London (London: I. B. Tauris \& Co. Ltd., 2015)

Pope, Alexander, Alexander Pope: The Major Works, ed. by Pat Rodgers (Oxford: Oxford University Press, 2008)

Poulton, Edward B., William John Burchell (London: Spottiswood \& Co Ltd, 1907)

Pound, Francis, 'Spectator Figures in Some New Zealand Paintings \& Prints', Art New Zealand, 23 (1982), 40-5

Pratt, Mary Louise, 'Fieldwork in Common Places', in Writing Culture: The Poetics and Politics of Ethnography, ed. by James Clifford and George E. Marcus (Berkeley: University of Berkeley Press, 1986)

- Imperial Eyes: Travel Writing and Transculturation (London: Routledge, 1992)

- Imperial Eyes: Travel Writing and Transculturation, 2nd edn (New York: Routledge, 2008)

Pulte, Helmut and Scott Mandelbrote, eds, The Reception of Isaac Newton in Europe, 3 vols (London: Bloomsbury Academic, 2019) 
Putten, Jan van der, 'Abdullah Munsyi and the Missionaries', Bijdragen tot de Taal-, Land-en Volkenkunde (BKI), 162.4 (2006), 407-40

Radhakrishnan, R., Theory in an Uneven World (Malden: Blackwell, 2003)

Raine, Philip, Paraguay (New Brunswick: Scarecrow Press, 1956)

Ramazani, Jahan, A Transnational Poetics (Chicago: Chicago University Press, 2009)

Reece, Bob, 'Rev, of Patrick Collins, Goodbye Bussamarai: The Mandandji Land War, Southern Queensland 1842-1852 (2002)', Bulletin (Australian Historical Association), 96 (2003), 78-82

Reeder, Jessie, The Forms of Informal Empire (Baltimore: Johns Hopkins University Press, 2020)

Reimer, Mavis, Clare Bradford, and Heather Snell, 'Juvenile Fiction', in The Oxford History of the Novel in English, Volume 9: The World Novel to 1950, ed. by Ralph Crane, Jane Stafford, and Mark Williams (Oxford: Oxford University Press, 2016), pp. 280-99

Rere, Taira, History of the Papehia Family (Suva: Lotu Pasifika Productions, 1977)

Rewi, Poia, Whaikōrero: The World of Māori Oratory (Auckland: Auckland University Press, 2010)

Rich, Paul B., Hope and Despair: English-Speaking Intellectuals and South African Politics, 1896-1976 (London: British Academic Press, 1993)

Rifkin, Mark, Beyond Settler Time: Temporal Sovereignty and Indigenous SelfDetermination (Durham: Duke University Press, 2017)

Roberts, David Andrew, “Language to Save the Innocent”: Reverend L. Threlkeld's Linguistic Mission', Journal of the Royal Australian Historical Society, 94.2 (2008), 107-25

Roberts, Jane, Royal Landscape: The Gardens and Parks of Windsor (New Haven and London: Yale University Press, 1997)

Roediger, David R., The Wages of Whiteness: Race and the Making of the American Working Class, revised edn (1991; repr. London: Verso, 2007)

Roff, William R., The Origins of Malay Nationalism (Singapore: Oxford University Press, 1994)

Rogers, Shef, 'Crusoe among the Maori: Translation and Colonial Acculturation in Victorian New Zealand', Book History, 1 (1998), 182-95

Rose, Deborah Bird, 'Gendered Substances and Objects in Ritual: An Australian Aboriginal Study', Material Religion, 3.1 (2007), 34-46

- 'An Indigenous Philosophical Ecology: Situating the Human', The Australian Journal of Anthropology, 16.3 (2005), 294-305

- Nourishing Terrains: Australian Aboriginal Views of Landscape and Wilderness (Canberra: Australian Heritage Commission, 1996)

- 'The Year Zero and the North Australian Frontier', in Tracking Knowledge in North Australian Landscapes: Studies in Indigenous and Settler Ecological Knowledge Systems, ed. by Deborah Rose and Anne Clarke (Casuarina: North Australia Research Unit, Australian National University, 1997), pp. 19-36

Rose, Jonathan, The Intellectual Life of the British Working Class (New Haven: Yale, 2001)

Ross, Lloyd, William Lane and the Australian Labor Movement (1935; repr. Sydney: Hale \& Iremonger, 1980)

Ross, Robert, 'The Kat River Rebellion and Khoikhoi Nationalism: The Fate of an Ethnic Identification', Kronos, 24 (1997), 91-105 
- Status and Respectability in the Cape Colony, 1750-1870: A Tragedy of Manners (Cambridge: Cambridge University Press, 1999)

- These Oppressions Won't Cease: The Political Thought of the Cape Khoesan, 1777-1879: An Anthology (Johannesburg: Witwatersrand University Press, 2017)

Ross, Trevor, The Making of the English Literary Canon: From the Middle Ages to the Late Eighteenth Century (Montreal and Kingston: McGill-Queen's University Press, 1998)

Rowse, Tim 'The Indigenous Redemption of Liberal Universalism', Modern Intellectual History, 12.3 (2015), 579-60

Rudy, Jason R., Imagined Homelands: British Poetry in the Colonies (Baltimore: Johns Hopkins University Press, 2017)

Russell, Lynette, ed., Colonial Frontiers: Indigenous-European Encounters in Settler Societies (Manchester: Manchester University Press, 2001)

- Roving Mariners: Australian Aboriginal Whalers and Sealers in the Southern Oceans, 1790-1870 (New York: State University of New York Press, 2012)

Ryan, Lyndall, 'Massacre in the Black War in Tasmania 1823-34: A Case Study of the Meander River Region, June 1827', Journal of Genocide Research, 10.4 (2008), 479-99

Ryan, Simon, The Cartographic Eye: How Explorers Saw Australia (Cambridge: Cambridge University Press, 1996)

Sadleir, Michael, Blessington-D’Orsay: A Masquerade (London: Constable, 1947)

Saha, Jonathan, 'No, You're Peripheral', 18 July 2013, n.p., https://colonizinganimals.blog/2013/07/18/no-youre-peripheral/ (accessed 5 April 2019)

Said, Edward, Orientalism (London: Pantheon, 1978)

- The World, the Text, and the Critic (Cambridge, MA: Harvard University Press, 1984)

Salesa, Damon Ieremia, 'The Pacific in Indigenous Time', in Pacific Histories: Ocean, Land, Peoples, ed. by David Armitage and Alison Bashford (Basingstoke: Palgrave Macmillan, 2014), pp. 31-52

- Racial Crossings: Race, Intermarriage, and the Victorian British Empire (Oxford: Oxford University Press, 2011)

Salmond, Anne, Hui: A Study of Maori Ceremonial Gatherings, revised edn (Auckland: Penguin, 2004)

- Tears of Rangi: Experiments across Worlds (Auckland: Auckland University Press, 2017)

- Two Worlds: First Meetings between Maori and Europeans, 1642-1772 (Auckland: Viking, 1991)

Samuelson, Meg, 'Rendering the Cape-as-Port: Sea-Mountain, Cape of Storms/Good Hope, Adamastor and Local-World Literary Formations', Journal of South African Studies, 42.3 (2016), 523-37

— and Charne Lavery, 'The Oceanic South', English Language Notes, 57.1 (2019), 37-50

Sanders, Andrew, 'British Colonial Policy and the Role of Amerindians in the Politics of the Nationalist Period in British Guiana, 1945-68', Social and Economic Studies, 36.3 (1987), 77-98

Santos, Boaventura de Sousa, Another Knowledge Is Possible: Beyond Northern Epistemologies (London and New York: Verso, 2008)

- The End of the Cognitive Empire: The Coming of Age of Epistemologies of the South (Durham: Duke University Press, 2018) 
Sartori, Andrew, Bengal in Global Concept History: Culturalism in the Age of Capital (Chicago: Chicago University Press, 2008)

- 'The Resonance of "Culture": Framing a Problem in Global Concept-History', Comparative Studies in Society and History, 47.4 (2005), 676-99

Saunders, Christopher, The Making of the South African Past: Major Historians on Race and Class (Totowa: Barnes \& Noble Books, 1988)

Sax, Boria, Imaginary Animals: The Monstrous, the Wondrous and the Human (London: Reaktion, 2013)

Scates, Bruce, 'Gender, Household and Community Politics: The 1890 Maritime Strike in Australia and New Zealand', Labour History, 61 (1991), 70-87

Schaffer, Kay, In the Wake of First Contact: The Eliza Fraser Stories (Cambridge: Cambridge University Press, 1995)

Scully, Richard, 'Britain in the Melbourne Punch', Visual Culture in Britain, 20.2 (2019), 152-71

Sedgwick, Eve Kosofsky, Touching Feeling: Affect, Pedagogy, Performativity (Durham and London: Duke University Press, 2003)

Selzer, Anita, Governors' Wives in Colonial Australia (Canberra: National Library of Canberra, 2002)

Serres, Michel, The Parasite, trans. Lawrence R. Schehr (Baltimore: Johns Hopkins University Press, 1982)

Seymour, A. J., 'The Literary Tradition: The Poetry of Egbert Martin (Leo)', in KykOver-Al, Volume 1, Issues 1-3, December 1945-December 1946 (Georgetown: Caribbean Press, 2013)

Shaikh, Fariha, Nineteenth-Century Settler Emigration in British Literature and Art (Edinburgh: Edinburgh University Press, 2018)

Shakespeare, Nicholas, In Tasmania (New York: Overlook Press, 2004)

Shapiro, Stephen, The Culture and Commerce of the Early American Novel: Reading the Atlantic World-System (University Park: Penn State University Press, 2008)

Shellam, Tiffany, Maria Nugent, Shino Konishi, and Alison Cadzow, eds, Brokers and Boundaries Colonial Exploration in Indigenous Territory (Canberra: Australian National University Press, 2016)

Silva, Denise Ferreira da, Toward a Global Idea of Race (Minneapolis: University of Minnesota Press, 2007)

Simons, John, Kangaroo (London: Reaktion, 2013)

Simpson, Kathryn, 'H. Rider Haggard, Theophilus Shepstone and the Zikali Trilogy: A Revisionist Approach to Haggard's African Fiction' (unpublished doctoral thesis, Edinburgh Napier University, 2016)

Sithole, Tendayi, Steve Biko: Decolonial Meditations of Black Consciousness (Lanham: Lexington Books, 2016)

Skilton, David, 'Contemplating the Ruins of London: Macaulay's New Zealander and Others', Literary London: Interdisciplinary Studies in the Representation of London, 2.2 (2004), n.p., http://literarylondon.org/the-literary-london-journal/archiveof-the-literary-london-journal/issue-2-1/contemplating-the-ruins-of-londonmacaulays-new-zealander-and-others/ (accessed 1 February 2020)

Skota, T. D. Mweli, The African Yearly Register: Being an Illustrated National Biographical Dictionary (Who's Who) of Black Folks in Africa (Johannesburg: R. L. Esson, 1939)

Skotnes, Pippa, ed., Miscast: Negotiating the Presence of the Bushmen (Cape Town: University of Cape Town Press, 1996) 
Slater, David, Geopolitics and the Post-Colonial: Rethinking North-South Relations (Oxford: Blackwell, 2004)

Sleight, Simon, 'Wavering between Virtue and Vice: Constructions of Youth in Australian Cartoons of the Late-Victorian Era', in Drawing the Line: Using Cartoons as Historical Evidence, ed. by Richard Scully and Marian Quartly (Clayton: Monash University ePress, 2009), pp. 194-239

Slezak, Michael, 'The Destruction of Australia's Landscape', Guardian (7 March 2018), n.p., www.theguardian.com/environment $/ 2018 / \mathrm{mar} / 07 /$ scorched-countrythe-destruction-of-australias-native-landscape (accessed 10 November 2019)

Sloterdijk, Peter, In the World Interior of Capital: Towards a Philosophical Theory of Globalization, trans. by Wieland Hoban (Cambridge: Polity, 2013)

Smith, Bernard, Modernism's History: A Study in Twentieth-Century Art and Ideas (Sydney: University of New South Wales Press, 1998)

Smith, Keith, Bennelong: The Coming in of the Eora, Sydney Cove 1788-1792 (East Roseville: Kangaroo Press, 2001)

Smith, Vanessa, 'Crusoe in the South Seas: Beachcombers, Missionaries and the Myth of the Castaway', in Robinson Crusoe: Myths and Metamorphoses, ed. by Lieve Spaas and Brian Stimpson (London: Macmillan, 1996), pp. 62-77

- Intimate Strangers: Friendship, Exchange and Pacific Encounters (Cambridge: Cambridge University Press, 2010)

- 'Joseph Banks's Intermediaries: Rethinking Global Cultural Exchange', in Global Intellectual History, ed. by Samuel Moyn and Andrew Sartori (New York: Columbia University Press, 2013), pp. 66-86

- Literary Culture and the Pacific: Nineteenth-Century Textual Encounters (Cambridge: Cambridge University Press, 1998)

Sopiee, Mohd Noordin, From Malayan Union to Singapore Separation: Political Unification in the Malaysia Region, 1945-65 (Kuala Lumpur: University of Malaya Press, 1974)

Southern Conceptualisms Network, n.p., www.museoreinasofia.es/en/southern-conceptualisms-network (accessed 26 June 2019)

Sparke, Matthew, 'Everywhere but Always Somewhere: Critical Geographies of the Global South', The Global South, 1.1 (2007), 117-26

Spender, Dale, Writing a New World: Two Centuries of Australian Women Writers (London and New York: Pandora, 1988)

Spitta, Silvia, Between Two Waters: Narratives of Transculturation in Latin America (Houston: Rice University Press, 1995)

Spivak, Gayatri Chakravorty, Death of a Discipline (New York: Columbia University Press, 2003)

— 'The Rani of Sirmur: An Essay in Reading the Archives', History and Theory, 24.3 (1985), 247-72

- 'Three Women's Texts and a Critique of Imperialism', Critical Inquiry, 12.1 (1985), 243-61

Spry, Adam, Our War Paint Is Writers' Ink: Anishinaabe Literary Transnationalism (Albany: SUNY Press, 2018)

Stallard, Avan Judd, Antipodes: In Search of the Southern Continent (Melbourne: Monash University Publishing, 2016)

Stampp, Kenneth, America in 1857: A Nation on the Brink (Oxford: Oxford University Press, 1990)

Standfield, Rachel, ed., Indigenous Mobilities: Across and Beyond the Antipodes (Canberra: Australian National University Press, 2018) 
Staple, J. H., 'Louis Becke's Gentleman Pirates and Lord Jim', The Conradian, 25.1 (2000), 72-82

Steer, Philip, 'The Historians, the Literary Critics, and the Victorian Settler Empire', Literature Compass, 15.5 (2018), 1-8

- Settler Colonialism in Victorian Literature: Economics and Political Identity in the Networks of Empire (Cambridge: Cambridge University Press, 2020)

Steinberg, Philip E., The Social Construction of the Ocean (Cambridge: Cambridge University Press, 2001)

Stern, Walter, 'The First London Dock Boom and the Growth of the West India Docks', Economica, new series, 19.73 (1952), 59-77

Stiebel, Lindy, Imagining Africa: Landscape in H. Rider Haggard's African Romances (Westport: Greenwood Press, 2001)

- 'A Map to Treasure: The Literary Significance of Thomas Baines's "Map of the Gold Fields of South Eastern Africa” (1875)', South African Historical Journal, 39 (1998), 64-9

— and Jane Carruthers, “The Last Hurrah”: Thomas Baines and the Expedition to the Coronation of Cetshwayo kaMpande, Zululand, 1873', Southern African Humanities, 32 (2019), 57-82

- and Jane Carruthers, eds, Thomas Baines: Exploring Tropical Australia, 1855 to 1857 (Canberra: National Museum of Australia, 2012)

- and Jane Carruthers, Vivian Forbes, and Norman Etherington, Thomas Baines: The Great Map (Durban: Campbell Collections of the University of Natal, 2001), CD

Stocking, Jnr, George W., 'What's in a Name? The Origins of the Royal Anthropological Institute (1837-71)', Man: Journal of the Royal Anthropological Institute, new series, 6.3 (1971), 369-90

Stoler, Ann Laura, 'Tense and Tender Ties: The Politics of Comparison in North American History and (Post) Colonial Studies', The Journal of American History, 88.3 (2001), 829-65

Stone, Jeffery, 'The Cartography of Thomas Baines', in Thomas Baines: Artist in Service of Science, ed. by Michael Stevenson (London: Christie's, 1999), pp. 118-29

Sturma, Michael, 'By Reef and Palm: Sexual Politics and South Seas Tales', Journal of Australian Studies, 21.53 (2009), 108-19

Sweeney, Amin, A Full Hearing: Orality and Literacy in the Malay World (Berkeley: University of California Press, 1987)

Switzer, Les, 'The African Christian Community and Its Press in Victorian South Africa (La communauté chrétienne africaine et sa presse dans l'Afrique du Sud victorienne)', Cahiers d'Études Africaines, 24.96 (1984), 455-76

Tacey, Ivan, 'Tropes of Fear: The Impact of Globalization on Batek Religious Landscapes', Religions, 4 (2013), 240-66

Tally, Robert T., Jr, The Routledge Handbook of Literature and Space (London: Taylor \& Francis, 2017)

Tan, Bonny, 'The Straits Chinese Magazine: A Malayan Voice', BiblioAsia, 7.2 (2011), 30-5

Teltscher, Kate, Palace of Palms: Tropical Dreams and the Making of Kew (London: Picador, 2020)

Te Punga Somerville, Alice, 'Canons: Damned If You Do and Damned If You Don't: A Response to Adam Kostsko', Australian Humanities Review, 60 (2016), 186-90 
- 'The Lingering War Captain: Maori Texts, Indigenous Contexts', Journal of New Zealand Literature, 24.2, Special Issue: Comparative Approaches to Indigenous Literary Studies (2007), 20-43

- 'Living on New Zealand Street: Maori Presence in Parramatta', Ethnohistory, 61.4 (2014), 655-9

- Once Were Pacific: Māori Connections to Oceania (Minneapolis: University of Minnesota Press, 2012)

Theal, George McCall, History of South Africa Since September 1795 (Cambridge: Cambridge University Press, 2010)

Thomas, Nicholas, 'Liberty and License: The Forsters' Accounts of New Zealand Sociality', in Voyages and Beaches: Pacific Encounters, 1769-1840, ed. by Alex Calder, Jonathan Lamb, and Bridget Orr (Honolulu: University of Hawai'i Press, 1999), pp. 132-55

Thomas, Sue, Imperialism, Reform, and the Making of Englishness in Jane Eyre (Basingstoke: Palgrave Macmillan, 2008)

Tiffin, Chris, 'Louis Becke, the Bulletin and By Reef and Palm', Kunapipi, 34.2 (2012), 163-9

Tonkin, Maggie, Mandy Treagus, Madeleine Seys, and Sharon Crozier-De Rosa, 'Re-visiting the Victorian Subject', in Changing the Victorian Subject, ed. by Maggie Tonkin, Mandy Treagus, Madeleine Seys, and Sharon Crozier-De Rosa (Adelaide: University of Adelaide Press, 2014), pp. 1-20

Trapido, Stanley, 'The Emergence of Liberalism and the Making of Hottentot Nationalism 1815-1834', Collected Seminar Papers. Institute of Commonwealth Studies, 42 (1992), 34-60

- 'From Paternalism to Liberalism: The Cape Colony, 1800-1834', The International History Review, 12.1 (1990), 76-104

Treagus, Mandy, "Crossing "The Beach": Samoa, Stevenson and the "Beach at Falesä"', Literature Compass, 11.5 (2014), 312-20

- Empire Girls: The Colonial Heroine Comes of Age (Adelaide: University of Adelaide Press, 2014)

Troy, Jakelin, 'The Sydney Language Notebooks and Responses to Language Contact in Early Colonial NSW', Australian Journal of Linguistics, 12.1 (1992), 145-70

Tsing, Anna, Friction: An Ethnography of Global Connection (Princeton: Princeton University Press, 2004)

Tuck, Eve, and K. Wayne Yang, 'Decolonization is not a Metaphor', Decolonization: Indigeneity, Education \& Society, 1.1 (2012), 1-40

Tuhiwai Smith, Linda, Decolonizing Methodologies: Research and Indigenous Peoples (Auckland: Zed, 1999)

Turnbull, C. M., A History of Modern Singapore, 1819-2005 (Singapore: National University of Singapore Press, 2009)

Tusan, Michelle, 'Empire and the Periodical Press', in The Routledge Handbook to Nineteenth-Century British Periodicals and Newspapers, ed. by Andrew King, Alexis Easley, and John Morton (London: Routledge, 2016), pp. 153-74

Vann, J. Don, and Rosemary T. VanArsdel, eds, Periodicals of Queen Victoria's Empire: An Exploration (Toronto: University of Toronto Press, 1996)

Van Toorn, Penny, Writing Never Arrives Naked (Canberra: Aboriginal Studies Press, 2006)

Veracini, Lorenzo, 'Introducing Settler Colonial Studies', Settler Colonial Studies, 1.1 (2011), 1-12 
Viswanathan, Gauri, Masks of Conquest: Literary Study and British Rule in India (New York: Columbia University Press, 1989)

Wafer, Jim, 'Ghost-Writing for Wulatji: Incubation and Re-Dreaming as Song Revitalisation Practices', in Recirculating Songs, ed. by Jim Wafer and Myfany Turpin (Canberra: Australian National University Press, 2017), pp. 193-256

— and Myfany Turpin, eds, Recirculating Songs: Revitalising the Singing Practices of Indigenous Australia (Canberra: Australian National University Press, 2017)

Wagner, Tamara S., 'Introduction: Narrating Domestic Portability: Emigration, Domesticity, and Genre Formation', in Victorian Settler Narratives: Emigrants, Cosmopolitans and Returnees in Nineteenth-Century Literature, ed. by Tamara S. Wagner (London: Pickering \& Chatto, 2011), pp. 1-22

Wallerstein, Immanuel, Historical Capitalism with Capitalist Civilization (London: Verso, 1996)

- The Modern World-System (New York: Academic Press, 1964)

Wallis, J. P. R., Thomas Baines: His Life and Explorations in South Africa, Rhodesia and Australia, 1820-1875, 2nd edn (Cape Town: A. A. Balkema, 1976)

Warren, Calvin L., Ontological Terror: Blackness, Nihilism, and Emancipation (Durham: Duke University Press, 2018)

Warren, Victoria, 'Marlowe's Older Brother: A Forgotten Australian, a Moral Morass, and the Last Free Islands of the South Pacific', Margins, 1 (2014), 16-24

Waterhouse, Richard, 'The Minstrel Show and Australian Culture', Journal of Popular Culture, 24 (1990), 147-66

Watson, Alex and Laurence Williams, 'British Romanticism in Asia, 1820-1950: Modernity, Tradition, and Transformation in India and East Asia', in British Romanticism in Asia: The Reception, Translation, and Transformation of Romantic Literature in India and East Asia, ed. by Alex Watson and Laurence Williams (Basingstoke: Palgrave Macmillan, 2019), pp. 1-38

Webby, Elizabeth, 'Australia', in Periodicals of Queen Victoria's Empire: An Exploration, ed. by J. Don Vann and Rosemary T. VanArsdel (Toronto: University of Toronto Press, 1996), pp. 19-60

Wenzlhuemer, Roland, 'The Ship, the Media, and the World: Conceptualizing Connections in Global History', Journal of Global History, 11.2 (2016), 163-86

Westmaas, Nigel David, 'A Mirror of Social and Political Ferment: The Newspaper Press of Guyana: 1838-1899' (unpublished doctoral thesis, Binghamton University, State University of New York, 2006)

Wevers, Lydia, Country of Writing: Travel Writing and New Zealand 1809-1900 (Auckland: Auckland University Press, 2002)

Wilderson III, Frank B., Red, White \& Black: Cinema and the Structure of U.S. Antagonisms (Durham: Duke University Press, 2010)

Wilentz, Sean, Chants Democratic: New York City and the Rise of the American Working Class, 1788-1850, 20th anniversary edn (Oxford: Oxford University Press, 2004)

Willan, Brian, 'What “Other Devils”? The Texts of Sol T. Plaatje's Mbudi Revisited', Journal of Southern African Studies, 41.6 (2015), 1331-47

Williams, John, 'Isidore, Orosius and the Beatus Map', Imago Mundi, 49 (1997), 7-32

Williams, Mark, ed., A History of New Zealand Literature (Cambridge: Cambridge University Press, 2016) 
Wolfe, Patrick, 'Settler Colonialism and the Elimination of the Native', Journal of Genocide Research, 8.4 (2006), 387-409

- Settler Colonialism and the Transformation of Anthropology: The Politics and Poetics of an Ethnographic Event (London and New York: Cassell, 1998)

Wong, Edlie L., Racial Reconstruction: Black Inclusion, Chinese Exclusion, and the Fictions of Citizenship (New York: New York University Press, 2015)

Wright, Christine, Wellington's Men in Australia: Peninsular War Veterans and the Making of Empire c. 1820-40 (Basingstoke: Palgrave Macmillan, 2011)

Wu, Duncan, “'A Vehicle of Private Malice”: Eliza Hamilton Dunlop and the Sydney Herald', The Review of English Studies, 65.272 (2014), 888-903

Yan, Shu-Chuan, “Kangaroo Politics, Kangaroo Ideas, and Kangaroo Society”: The Early Years of Melbourne Punch in Colonial Australia', Victorian Periodicals Review, 52.1 (2019), 80-102

Young, Sally, Paper Emperors: The Rise of Australia's Newspaper Empires (Sydney: University of New South Wales Press, 2019)

Zhan, Mei, Other-Worldly: Making Chinese Medicine through Transnational Frames (Durham: Duke University Press: 2009) 